\title{
Tissue depletion study of enrofloxacin and its metabolite ciprofloxacin in broiler chickens after oral administration of a new veterinary pharmaceutical formulation containing enrofloxacin
}

\author{
Karina P.D. Bonassa ${ }^{a,}{ }^{*}$, Miwa Y. Miragliotta ${ }^{\text {a }}$, Rosineide C. Simas ${ }^{\text {b }}$, Diego A. Monteiro ${ }^{\text {d }}$, \\ Marcos N. Eberlin ${ }^{\mathrm{b}}$, Arturo Anadón ${ }^{\mathrm{c}}$, Felix G.R. Reyes ${ }^{\mathrm{a}}$ \\ a School of Food Engineering, Department of Food Sciences, University of Campinas - UNICAMP, Campinas, SP, Brazil \\ ${ }^{\mathrm{b}}$ ThoMSon Mass Spectrometry Laboratory, Institute of Chemistry, University of Campinas - UNICAMP, Campinas, SP, Brazil \\ ${ }^{c}$ Department of Toxicology and Pharmacology, Faculty of Veterinary Medicine, Universidad Complutense de Madrid, 28040 Madrid, Spain \\ d Biosciences, Languages and Exact Sciences Institute - (IBILCE), Júlio de Mesquita Filho University - UNESP, São José do Rio Preto, SP, Brazil
}

\section{A R T I C L E I N F O}

\section{Article history:}

Received 4 December 2016

Received in revised form

29 January 2017

Accepted 21 March 2017

Available online 23 March 2017

\section{Introduction}

Enrofloxacin (ENR) (1-cyclopropyl-7-(4-ethylpiperazin-1-yl)-6fluoro-4-oxoquinoline-3-carboxylic acid) belongs to the family of 6-fluoro-7-piperazinyl-4-quinolones. This antimicrobial is highly lipophilic and the addition of a carboxylic acid and a tertiary amine contributes to the amphoteric properties of ENR. Depending on the $\mathrm{pH}$ of the environment, fluoroquinolones (FQ's) may exist under the cationic, anionic, neutral or ion-dipolar forms, which may influence the pharmacological behavior of these compounds with bactericidal and concentration-dependent characteristics (Aldred et al., 2014; De Sarro and De Sarro, 2001; Rusu et al., 2012). ENR is a pharmacologically active substance of high effectiveness against Gram-positive and Gram-negative bacteria and it is for veterinary use only. On the other hand, we should be concerned with the indiscriminate usage of these FQ's, since there is historical information that CIP used to treat diseases of human beings was the most consumed antimicrobial in the world in the first decade of this century. This fact facilitates the spreading of rapid development of bacterial resistance to FQ's (Górniak, 2011). The use of ENR in poultry should be performed only for therapeutic purposes and situations wherein the disease has been diagnosed and needs to be

\footnotetext{
* Corresponding author.

E-mail address: karinapaduarte@yahoo.com.br (K.P.D. Bonassa).
}

treated (Pereira, 2009).

FQ's are recognized as veterinary important antimicrobials in the treatment of colibacilosis, septicaemia and chronic respiratory disease in poultry with few effective alternatives. The active metabolite of ENR, CIP, is classified as a "critically important antibiotic" for use in human medicine (BEUC, 2014). It is a known fact that the use of antimicrobials, either in humans or in veterinary medicine, particularly in food animals, is a risk factor for antimicrobial resistance. The use of ENR in food animals has resulted in the development of resistance in Salmonella and Campylobacter to CIP.

Ensuring the prudent and responsible use of ENR in veterinary medicines respecting the dose regime and withdrawal period, is the key to effectively minimize risk from antimicrobial resistance.

Edible tissues containing veterinary drug residues may pose risks to human health, including direct toxic effects, allergic reactions and increased bacterial resistance to antimicrobials commonly used for the treatment of animals and humans (Anadón et al., 2012; Companyo et al., 2009; Goetting et al., 2011).

To protect human health, MRLs of pharmacologically active substances are established by regulatory agencies and their respective withdrawal period of antimicrobial administration, before slaughter, should be broadly and individually studied based on MRL values in the target tissues (i.e. muscle, skin/fat, liver, and kidney) of each animal species. Thus, if the antimicrobial residue levels in the target tissues are below the established MRL values, it is considered that its presence in food does not represent a risk to consumer health (Anadón et al., 2001, 2012; Palermo Neto, 2004).

There is a strict legislative framework controlling the use of antimicrobial substances with the aim of minimizing the risk to human health associated with consumption of their food residues. Therefore, to ensure human food safety, the European Union (EU), under Commission Regulation (EU) $n^{\circ}$. 37/2010 establishes that the sum of ENR + CIP MRL's in chickens must be $100 \mu \mathrm{g} / \mathrm{kg}$ in muscle, $100 \mu \mathrm{g} / \mathrm{kg}$ in skin/fat, $200 \mu \mathrm{g} / \mathrm{kg}$ in liver, and $300 \mu \mathrm{g} / \mathrm{kg}$ in kidney 
(EU, 2010). However, the Ministry of Health, Labour and Welfare in Japan establishes that the sum of ENR and CIP MLR's in chickens must be $50 \mu \mathrm{g} / \mathrm{kg}$ in muscle, $50 \mu \mathrm{g} / \mathrm{kg}$ in skin/fat, $100 \mu \mathrm{g} / \mathrm{kg}$ in liver, and $100 \mu \mathrm{g} / \mathrm{kg}$ in kidney (JPL, 2006). These low values demand the development of fully validated analytical methods with selectivity, accuracy, reproducibility and reliability to monitor and determine the antimicrobial residue levels in animal edible tissues to establish the withdrawal period before slaughtering the food animals.

Traditionally, fluoroquinolone (FQ) residue determination levels have been based on analytic methods such as liquid chromatography (LC) with ultraviolet detector (Bailac et al., 2004; Yu et al., 2012), diode array (DAD) (Moema et al., 2012), fluorescence (Garcia-Ovando et al., 2000; Garcia et al., 2001; Pena et al., 2010; Severo, 1999), mass spectrometry (Bailac et al., 2006; Bousova et al., 2013; Ferrari et al., 2015; San Martín et al., 2007; San Martín et al., 2009; Yu et al., 2012) or capillary electrophoresis (Barrón et al., 2001). Currently, the major challenge for main research centers is to keep methodologies updated in order to meet commercial and tread requirements and ensure human health integrity.

There are a high number of studies and reviews in the open literature addressing quinolones, but the development of accurate and sensitive methods of determination and characterization of quinolones in foods of animal origin would be of great interest to ensure its safety and to reduce the risks to human health.

This study refers to a new veterinary pharmaceutical formulation (contains a nominal concentration of $25 \%$ ENR) and describes the rate of depletion of ENR and its metabolite CIP in edible tissues of healthy broiler chickens after multiple-dose oral administration (by gavage) using liquid chromatography-tandem mass spectrometry (LC-MS/MS), a sensitive methodology with excellent quality parameters and reduced time of analysis (Barbosa et al., 2009; Ferrari et al., 2015) to determine its withdrawal period.

\section{Materials and methods}

\subsection{Chemicals and reagents}

Analytical standards of ENR and CIP were purchased from Dr Ehrenstorfer GmbH (Augsburg, Germany), and CIP-d8 hydrochloride hydrate (internal standard, IS) was purchased from SigmaAldrich (St. Louis, MO, USA). Solid phase extraction (SPE) cartridges, Strata-X polymeric reversed phase $(60 \mathrm{mg} / 3 \mathrm{~mL})$ were purchased from Phenomenex (Torrance, CA, USA). All chromatographic solvents used in this study were HPLC grade, and water was purified by distillation and passage through a Milli-Q system (Millipore, Bedford, MA, USA).

\subsection{Veterinary pharmaceutical formulation}

The ENR hydrochloride (99\% purity) used in this study was from Shangyu Jingxin Pharmaceutical Co. Ltd., Shangyu, China, which was used to produce a new veterinary pharmaceutical formulation (batch number DK05-1306071) that contains a nominal concentration of 25\% ENR. This new pharmaceutical formulation will be commercialized in powder to be diluted in drinking water for its administration. Prior to use in this study, the real concentration of ENR in the formulation was determined by a validated HPLCFluorescence detector analytical method.

\subsection{Animals}

This study was undertaken in accordance with the ethics requirements and authorized by the official ethics committee of University of Campinas (Protocol number 3135-1). Forty-eight male and female clinically healthy broiler chickens (commercial Gallus gallus domesticus) ( $\mathrm{Cobb}^{\circledR}$ ) were used in equal proportions. All chickens were obtained from a commercial farm (Agroceres, Patrocínio, Minas Gerais, Brazil), 28 days old, with an average weight of $1.5-2.0 \mathrm{~kg}$. The chickens were placed in experimental floor pens and maintained for a 7-day acclimation period prior to the study. The environmental conditions of the place were $25{ }^{\circ} \mathrm{C} \pm 5{ }^{\circ} \mathrm{C}$ of temperature, $50-60 \%$ relative humidity with ad libitum access to water. The food provided was formulated according to nutrient requirements for broilers chickens being growth for market, and was free of any antimicrobial drug.

\subsubsection{Experimental design}

On the 7th day of acclimation, broiler chickens were weighed and randomly allocated into six experimental groups of 8 chickens each ( 4 males and 4 females). They were identified by A, B, C, D, E, F groups, and were treated individually with $10 \mathrm{mg} / \mathrm{kg}$ body weight (BW), orally administered, once per day for 5 consecutive days. The veterinary pharmaceutical formulation was administered orally (by gavage) using a rubber tube attached at syringe to ensure the complete ingestion of the dose.

Six chickens of each group were euthanized by cervical dislocation at 1, 3, 5, 6, 7 and 10 days' post-treatment and sample tissue of the 2 kidneys, liver (clean without gallbladder), muscle (pectoralis major) and skin/fat (breast with fat in natural proportions) were collected separately and stored at $-20^{\circ} \mathrm{C}$ previously to analysis by LC-MS/MS.

\subsection{Analytical method and validation}

ENR and CIP concentrations in target tissues were determined by liquid chromatography-tandem mass spectrometry (LC-MS/MS) using electrospray as ionization source (ESI+) (Ferrari et al., 2015). The developed analytical method was validated taking into consideration the European Decision Commission 2002/657/EC (EC, 2002) and the International Cooperation on Harmonization of Technical Requirements for Registration of Veterinary Medicinal Products requirements (VICH, 1999).

\subsubsection{Sample preparation}

Muscle or skin/fat tissue ( $0.5 \mathrm{~g})$ and kidney or liver tissue $(0.3 \mathrm{~g})$ were accurately weighed and placed into $2 \mathrm{~mL}$ plastic microtubes. Next, $20 \mu \mathrm{L}$ of the internal standard (IS) solution at $20 \mu \mathrm{g} / \mathrm{g}$ was added and incubated for $15 \mathrm{~min}$ at $5{ }^{\circ} \mathrm{C}$. Then, $1000 \mu \mathrm{L}$ of methanol $(\mathrm{MeOH})$ with $0.1 \%$ formic acid was added, followed by shaking for $10 \mathrm{~min}$ at $1000 \mathrm{rpm}$. The mixture was then centrifuged at $18 \mathrm{000 \textrm {g }}$ for $5 \mathrm{~min}$. The organic phase was transferred to a $15 \mathrm{~mL}$ falcon tube. The residue was washed twice with $800 \mu \mathrm{L}$ of $\mathrm{MeOH}$ with $0.1 \%$ formic acid. Next, $12 \mathrm{~mL}$ of water was added to the recovered organic extract of all types of samples (muscle, skin/fat, liver and kidney). The SPE cartridges used for sample clean up were activated with $2 \mathrm{~mL}$ of acetonitrile (ACN) and $2 \mathrm{~mL}$ of water. After passing through the SPE cartridges, the samples were cleaned with $2 \mathrm{~mL}$ of water and $3 \mathrm{~mL}$ of hexane. For ENR and CIP elution, $5 \mathrm{~mL}$ of mobile phase, which consisted of ACN with $0.1 \%$ formic acid and water with $0.1 \%$ formic acid $(60: 40, \mathrm{v} / \mathrm{v})$ with $5 \mathrm{mM}$ EDTA, were used. Then, $1000 \mu \mathrm{L}$ of the SPE resulting extract was placed into amber glass vials and used for injection into the LC-MS/MS system.

\subsection{2. $L C-M S / M S$ analysis}

Concentrations of ENR and CIP in target tissues were measured using an HPLC system (Agilent Technologies 1260 series, Waldbronn, Germany) coupled to a Q-TRAP 5500 tandem mass spectrometer (Sciex, Concord, ON, CA) equipped with an electrospray source and the Analyst 1.6.1 and MultiQuant 1.3.1 softwares. All 
samples were analyzed using a Kinetex PFP $100 \AA$ reversed phase column (00B-4462-E0, $100 \mathrm{~mm} \times 4.6 \mathrm{~mm}$ i.d., $2.6 \mu \mathrm{m}$ particle size, Phenomenex, Torrance, CA, USA) with a compatible pre-column (PFP, PN AJ0-8773, Phenomenex, Torrance, CA) at a flow rate of

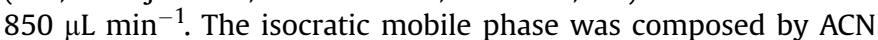
with $0.1 \%$ formic acid and deionized water with $0.1 \%$ formic acid (60:40, v/v) with isocratic elution mode. Full data on the development and validation of the analytical method was published by Ferrari et al. (2015).

The ESI source was operated in the positive ion mode (ESI+), nitrogen was used as curtain (10 psi), nebulizer (40 psi), auxiliary (15 psi) and collision (high or 12 a.u.) gas, the ion transfer voltage was set to $4500 \mathrm{~V}$ and the probe temperature to $650^{\circ} \mathrm{C}$. MS data on precursor and product ions were collected in multiple reactions monitoring mode (MRM). The optimized MS/MS conditions for ENR, CIP and deuterated internal standard CIP (CIP-d8) analysis are in Table 1.

\subsubsection{Validation of analytical method}

The analytical method was fully validated taking into consideration the European Decision Commission 2002/657 (EC, 2002) and VICH (1999) requirements, using control samples of target tissues of broiler chickens (muscle, skin/fat, liver, kidney) as matrix. The following parameters were evaluated: extraction efficiency, linearity, selectivity, intra and inter-day precisions, matrix effects, accuracy, decision limits (CC $\alpha$ ), detection capability $(C C \beta)$, limit of detection (LOD), limit of quantitation (LOQ), susceptibility to interference and stability of the analyte during the analysis. Analytical curves were determined for target tissue samples from untreated broiler chickens and were spiked with known concentrations of ENR and CIP. The calibration curve of ENR and CIP used was in the range of $1-150 \mu \mathrm{g} / \mathrm{kg}$ (ENR and CIP) for skin/fat, $2-350 \mu \mathrm{g} / \mathrm{kg}$ (ENR) and $2-80 \mu \mathrm{g} / \mathrm{kg}$ (CIP) for muscle, and 5-500 $\mu \mathrm{g} /$ $\mathrm{kg}$ (ENR and CIP) for kidney and liver.

\subsection{Data analysis}

Data obtained was calculated with the withdrawal period calculation program WT 1.4 that was recommended by the Committee for Veterinary Medicinal Products EMEA/CVMP/036/95 (EMEA, 1996). This guide recommends to consider the linear regression technique of log-transformation; it was determined as the time when the one-sided 95\% upper tolerance limit of the regression line was below the MRL with 95\% confidence.

\section{Results and discussion}

\subsection{Analytical method}

In this study, the use of an analytical method with high selectivity, accuracy, reproducibility and reliability was of high

\section{Table 1}

Optimized MS/MS conditions for enrofloxacin (ENR), ciprofloxacin (CIP) and deuterated internal standard CIP (CIP-d8).

\begin{tabular}{lllllll}
\hline Analyte & {$\left[\mathrm{M}+\mathrm{H}^{+}\right]$} & $\mathrm{m} / \mathrm{z}$ & $\mathrm{DP}(\mathrm{V})$ & $\mathrm{EP}(\mathrm{V})$ & $\mathrm{CE}(\mathrm{V})$ & $\mathrm{CXP}(\mathrm{V})$ \\
\hline ENR & 360 & $245^{\mathrm{a}}$ & 146 & 10 & 37 & 16 \\
& & $203^{\mathrm{b}}$ & & & 53 & 6 \\
CIP & 332 & $314^{\mathrm{a}}$ & 91 & & 33 & 6 \\
& & $231^{\mathrm{b}}$ & & 49 & 12 \\
CIP-d8 & 340 & 296 & 251 & & 30 & 8 \\
\hline
\end{tabular}

Abbreviations: $\mathrm{DP}=$ declustering potential; $\mathrm{CE}=$ collision energy; $\mathrm{EP}=$ entrance potential; $\mathrm{CXP}=$ collision cell exit potential.

a Quantitation ion.

b Confirmation ion. importance for the credibility of the data results obtained, in order to guarantee and protect consumer's health and meet the veterinary medicinal product regulations of different countries.

In the past, several published studies about residues of pharmacologically active substances on biological tissues used analytical methods not so precise, and even when we talk about mass spectrometry equipment it is important to remind that over the past decade, various mass spectrometers introduced were capable of selective, sensitive detection of residues in just a comprehensive way only. Of all LC-MS applications on residues of food animal determination, $90 \%$ relied on a mass spectrometer capable of full mass spectra acquisition, usually mass spectra acquisition using MRM. However, recent advances in LC-MS have revolutionized residues of food animal determination increasing the chromatographic separation power and sensitivity of detection. This was the case for the method developed and validated in our study for the ENR and CIP residue determination in broiler chicken tissues, which brought us results with great sensitivity and precision, and allowed fast chromatographic runs with low use of organic solvents. Additional care was taken with the use of deuterated internal standard CIP-d8 to correct random, systematic errors, matrix effect and sample preparation.

It is important to highlight that the results from this residue depletion study were obtained through a single sample preparation for the different matrices, which is very rare in the current literature, facilitating the reproduction of the method developed (Ferrari et al., 2015). Also, it was possible to obtain extraordinary data results with analytical curves showing a correlation coefficient exceeding 0.999 and an overall recovery of ENR and CIP from target tissues greater than $98 \%$ and $97 \%$ respectively. The LOQ for ENR and CIP was $1 \mu \mathrm{g} / \mathrm{kg}$ for skin/fat, $2 \mu \mathrm{g} / \mathrm{kg}$ for muscle and $5 \mu \mathrm{g} / \mathrm{kg}$ for both kidney and liver.

\subsection{Tissue residue depletion}

The new veterinary pharmaceutical formulation containing ENR was administered orally by gavage $(10 \mathrm{mg} / \mathrm{kg}$ BW daily during 5 consecutive days) and ENR and CIP were quantified. CIP was evaluated because it is the main metabolite generated from ENR biotransformation, and ENR + CIP was considered as the target residue (EMEA, 1996). Data results of the tissue residue levels of ENR, CIP and ENR + CIP in muscle, skin/fat, liver and kidney are presented in Table 2. The average concentration of ENR and CIP varied between $4231 \pm 530$ to $748 \pm 241 \mu \mathrm{g} / \mathrm{kg}$ and $3371 \pm 261$ to $92.7 \pm 34 \mu \mathrm{g} / \mathrm{kg}$ respectively, determined after one day from the last administered dose of ENR (Table 2). It was shown that the concentration of ENR in the skin/fat depletes more slowly than in the muscle, liver and kidney tissues.

ENR was quantified in muscle $(2.27 \pm 0.83 \mu \mathrm{g} / \mathrm{kg})$, skin/fat $(12.70 \pm 3.13 \mu \mathrm{g} / \mathrm{kg})$, liver $(9.96 \pm 2.39 \mu \mathrm{g} / \mathrm{kg})$ and kidney $(5.11 \pm 1.19 \mu \mathrm{g} / \mathrm{kg})$ even at ten days after the end of treatment. From the four analyzed tissues, skin/fat and liver showed the highest ENR and CIP residue level at the end of the study (Table 2).

\subsection{Withdrawal period estimation}

Statistics methodology applied on data analysis of this study follows the recommendation of the Committee for Veterinary Medicinal Products (EMEA), using the linear regression analysis of the logarithmic transformation data techniques (EMEA, 1996). Using this concept, the withdrawal period was determined as the time when the one-sided 95\% upper tolerance limit of the regression line with $95 \%$ confidence level was below the MRL values and analysis of homogeneity of variances.

The withdrawal period for this veterinary medicinal product 
Table 2

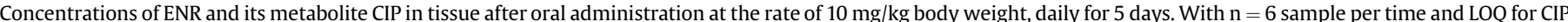
in muscle $=2 \mu \mathrm{g} / \mathrm{kg}$ and kidney $=5 \mu \mathrm{g} / \mathrm{kg}$.

\begin{tabular}{|c|c|c|c|c|}
\hline Tissue $(\mu \mathrm{g} / \mathrm{kg})$ & Time after last dose (days) & $\begin{array}{l}\text { ENR } \\
(\text { mean } \pm S D)\end{array}$ & $\begin{array}{l}\text { CIP } \\
(\text { mean } \pm S D)\end{array}$ & $\begin{array}{l}\text { Sum }(\text { ENR }+ \text { CIP }) \\
(\text { mean } \pm \text { SD })\end{array}$ \\
\hline muscle & $\begin{array}{l}1 \\
3 \\
5 \\
6 \\
7 \\
10\end{array}$ & $\begin{array}{l}2059.03 \pm 517.24 \\
81.35 \pm 25.71 \\
27.85 \pm 4.81 \\
15.03 \pm 2.13 \\
3.40 \pm 0.83 \\
2.27 \pm 0.83\end{array}$ & $\begin{array}{l}163.23 \pm 42.70 \\
7.29 \pm 3.26 \\
4.84 \pm 0.72 \\
3.27 \pm 0.81 \\
2.15 \pm 0.25 \\
<\text { LOQ }\end{array}$ & $\begin{array}{l}2222.26 \pm 555.59 \\
88.64 \pm 28.03 \\
32.69 \pm 5.12 \\
18.30 \pm 2.72 \\
5.56 \pm 0.92 \\
2.27 \pm 0.83\end{array}$ \\
\hline skin/fat & $\begin{array}{l}1 \\
3 \\
5 \\
6 \\
7 \\
10\end{array}$ & $\begin{array}{l}747.71 \pm 241.36 \\
91.27 \pm 10.09 \\
68.09 \pm 10.48 \\
42.53 \pm 11.84 \\
26.29 \pm 6.68 \\
12.70 \pm 3.13\end{array}$ & $\begin{array}{l}92.66 \pm 33.60 \\
15.57 \pm 1.90 \\
13.44 \pm 2.48 \\
8.38 \pm 1.53 \\
4.71 \pm 1.99 \\
2.33 \pm 0.85\end{array}$ & $\begin{array}{l}840.37 \pm 271.97 \\
106.84 \pm 11.66 \\
81.54 \pm 10.76 \\
50.91 \pm 12.52 \\
31.00 \pm 8.47 \\
15.03 \pm 3.87\end{array}$ \\
\hline Liver & $\begin{array}{l}1 \\
3 \\
5 \\
6 \\
7 \\
10\end{array}$ & $\begin{array}{l}4230.62 \pm 530.04 \\
233.53 \pm 34.73 \\
71.25 \pm 19.95 \\
41.70 \pm 19.84 \\
16.74 \pm 2.12 \\
9.96 \pm 2.39\end{array}$ & $\begin{array}{l}3370.92 \pm 260.94 \\
151.27 \pm 37.89 \\
45.09 \pm 23.40 \\
30.74 \pm 11.80 \\
12.02 \pm 4.58 \\
8.57 \pm 2.44\end{array}$ & $\begin{array}{l}7601.54 \pm 743.98 \\
384.80 \pm 34.67 \\
116.33 \pm 35.72 \\
72.44 \pm 32.67 \\
28.77 \pm 6.80 \\
18.53 \pm 4.87\end{array}$ \\
\hline Kidney & $\begin{array}{l}1 \\
3 \\
5 \\
6 \\
7 \\
10\end{array}$ & $\begin{array}{l}3583.68 \pm 1709.90 \\
120.40 \pm 55.91 \\
28.55 \pm 10.39 \\
14.21 \pm 1.27 \\
8.04 \pm 1.75 \\
5.11 \pm 1.19\end{array}$ & $\begin{array}{l}915.46 \pm 656.34 \\
41.99 \pm 19.32 \\
7.38 \pm 1.29 \\
6.46 \pm 1.20 \\
5.39 \pm 0.05 \\
<\text { LOQ }\end{array}$ & $\begin{array}{l}4499.14 \pm 2355.17 \\
162.38 \pm 72.81 \\
35.93 \pm 10.99 \\
20.67 \pm 2.30 \\
13.43 \pm 1.71 \\
5.11 \pm 1.19\end{array}$ \\
\hline
\end{tabular}

containing ENR was calculated for muscle, skin/fat, liver and kidney tissues after oral administration $(10 \mathrm{mg} / \mathrm{kg} \mathrm{BW}$, daily for 5 consecutive days), resulting in a final withdrawal period of 8 days for the European Union regulation and 9 days for the MRLs positive list of the Ministry of Health Labour and Welfare of Japan. The results for muscle, skin/fat, liver and kidney tissues are presented in Table 3. Figs. 1 and 2 illustrate a plot of withdrawal period calculation for ENR + CIP target residue in the liver of broiler chickens after oral administration ( $10 \mathrm{mg} / \mathrm{kg} \mathrm{BW}$, daily for 5 consecutive days).

This study is the first to clearly report a comparison between 2 legislative frameworks (European Union and Japanese government), and considering all target tissues involved in the requirements for the approval of new veterinary pharmaceutical formulation, and presenting reliable data from the standpoint of high sensibility analysis, which allows us to ensure the quality of the results expressed.

Accordingly, the outcomes from this tissue depletion study do not present values that are below the LOQ in the time (days) in which the withdrawal period was calculated. That is, until the 8 and 9 days, respectively, for the European Union and Japanese government requirements.

Data from published scientific literature indicate relevant differences between pharmaceutical formulations using the same pharmacologically active substance which result in variations of the withdrawal period. As literature references, it is possible to mention a study from San Martín et al. (2009), which worked with the liver using the EU reference of MLR of $200 \mu \mathrm{g} / \mathrm{kg}$, and found withdrawal periods of 3 and 4 days for several galenic formulations containing ENR; as well as a study from Anadón et al. (1995) analyzed ENR and CIP by HPLC, who found a withdrawal period of 12 days for a water solution with ENR.

Thus, there are evidences that the pharmaceutical formulation can generate relevant effects on the animal tissue depletion of a veterinary drug (Kukanich et al., 2005), and the effectiveness of a drug is dependent on its route of administration and metabolic pattern (Alvinerie et al., 1999). The main concern when using FQ's is to preserve human health because drug residues in foods could produce acute toxic effects and/or chronic long-term effects. Thus, the MRLs values established should be respected, as well as the withdrawal period determined for each pharmaceutical formulation (Anadón et al., 2012).

\section{Conclusion}

The fully validated LC-MS/MS method used in this study for quantitation of ENR and CIP residues in the 4 chicken target tissues evaluated (muscle, skin/fat, liver, kidney) was adequate to the intended purpose. The outcome from the tissue depletion study indicate that the new veterinary pharmaceutical formulation containing ENR has a withdrawal period of 8 and 9 days, based on the European Union and Japanese government requirements, respectively. This study is useful to regulatory bodies with the view to protect the consumer health from the risk arising from the

Table 3

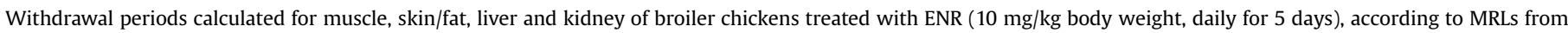
European Union - EU (EU, 2010) and Japan Ministry of Health Labour and Welfare (JPL, 2006).

\begin{tabular}{|c|c|c|c|c|c|c|c|c|}
\hline \multirow{2}{*}{$\begin{array}{l}\text { Tissue } \\
\text { Legislative framework }\end{array}$} & \multicolumn{2}{|c|}{ Muscle } & \multicolumn{2}{|c|}{ Skin/fat } & \multicolumn{2}{|c|}{ Liver } & \multicolumn{2}{|c|}{ Kidney } \\
\hline & EU & Japan & EU & Japan & EU & Japan & EU & Japan \\
\hline MRL (sum of ENR and CIP) $(\mu \mathrm{g} / \mathrm{kg})$ & 100 & 50 & 100 & 50 & 200 & 100 & 300 & 100 \\
\hline Withdrawal period (days) & 6 & 7 & 7 & 9 & 8 & 9 & 6 & 7 \\
\hline
\end{tabular}




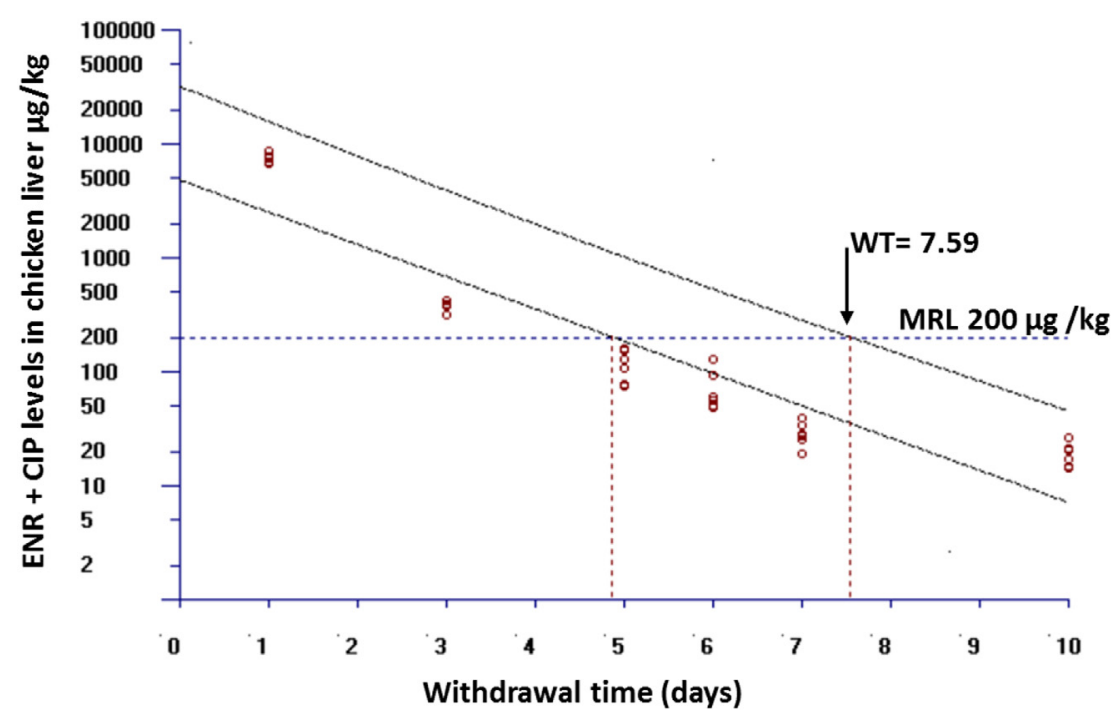

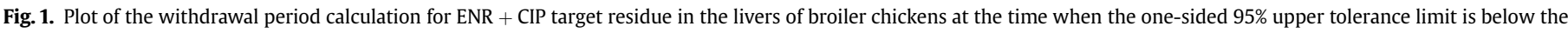
EU MRL for ENR $(200 \mu \mathrm{g} / \mathrm{kg})$ after oral administration of ENR (10 mg/kg body weight, daily for 5 days).

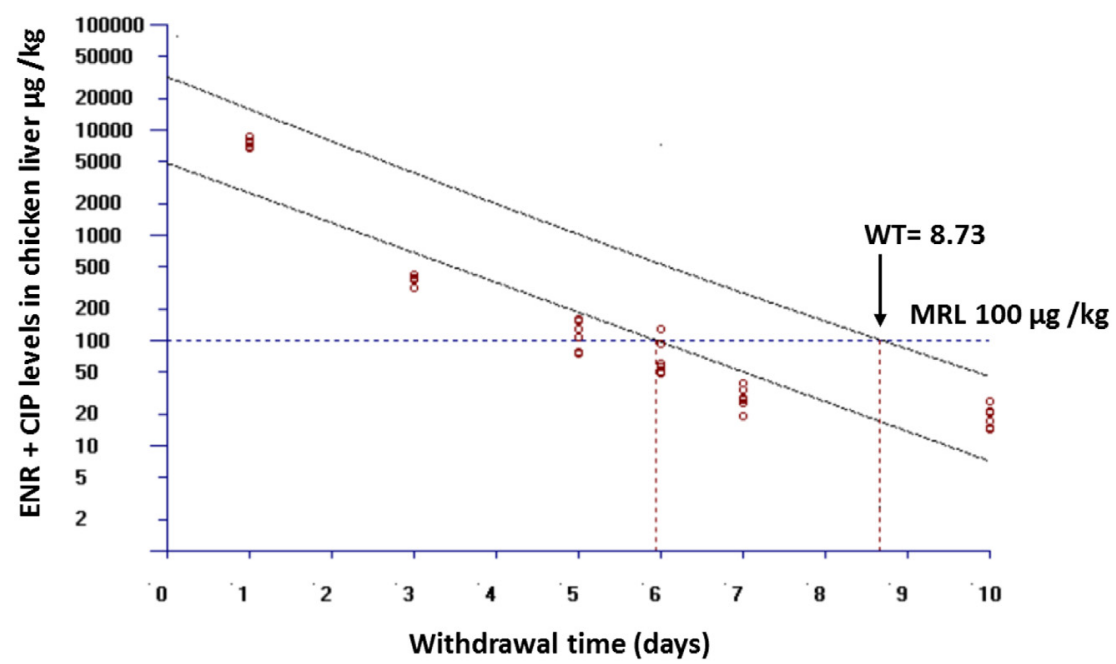

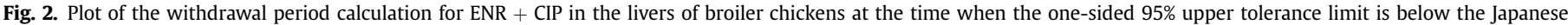

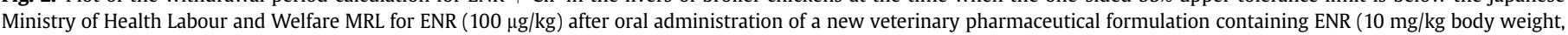
daily for 5 days).

exposure to the antimicrobial ENR and CIP present in broiler chicken meat and offal, as well as to facilitate international trade of this important food commodity.

\section{Conflict of interest}

The authors declare that there are no conflicts of interest.

\section{Acknowledgments}

This work was supported by the Brazilian National Council for Scientific and Technological Development (CNPq Process No. 305390/2013-9) and Agroceres Multimix, Brazil.

\section{Appendix A. Supplementary data}

Supplementary data related to this article can be found at http:// dx.doi.org/10.1016/j.fct.2017.03.033.

\section{Transparency document}

Transparency document related to this article can be found online at http://dx.doi.org/10.1016/j.fct.2017.03.033.

\section{References}

Aldred, K.J., Kerns, R.J., Osheroff, N., 2014. Mechanism of quinolone action and resistance. Biochemistry 53, 1565-1574.

Alvinerie, M., Lacoste, E., Sutra, J.F., Chartier, C., 1999. Some pharmacokinetic parameters of eprinomectin in goats following pour-on administration. Veterinary Res. Commun. 23, 449-455.

Anadón, A., Martínez-Larrañaga, M.R., Castellano, V., 2012. Regulatory aspects for the drugs and chemicals used in food-producing animals in the European Union. In: Gupta, Ramesh C. (Ed.), Veterinary Toxicology. Academic Press, Oxford, pp. 135-155.

Anadón, A., Martínez-Larrañaga, M.R., Iturbe, J., Martínez, M.A., Díaz, M.J. Frejo, M.T., Martínez, M., 2001. Pharmacokinetics and residues of ciprofloxacin and its metabolites in broiler chickens. Res. Veterinary Sci. 71, 101-109.

Anadón, A., Martínez-Larrañaga, M.R., Díaz, M.J., Bringas, P., Martínez, M.A. Fernández-Cruz, M.L., Fernández, M.C., Fernández, R., 1995. Pharmacokinetics and residues of enrofloxacin in chickens. Am. J. Veterinary Res. 56 (4), 501-506. 
Bailac, S., Barrón, D., Sanz-Nebot, V., Barbosa, J., 2006. Determination of fluoroquinolones in chicken tissues by LC-coupled electrospray ionization and atmospheric pressure chemical ionization. J. Sep. Sci. 29, 131-136.

Bailac, S., Ballesteros, O., Jiménez-Lozano, E., Barrón, D., Sanz-Nebot, V., Navalón, A. Vilchez, J.L., Barbosa, J., 2004. Determination of quinolones in chicken tissues by liquid chromatography with ultraviolet absorbance detection. J. Chromatogr. A 1029, 145-151.

Barbosa, J., Barrón, D., Hermo, M.D.P., Navalón, A., Ballesteros, O., 2009. Determination and characterization of quinolones in foodstuffs of animal origin by CEUV, LC-UV, LC-FL, LC-MS, and LC-MS/MS. Ovidius Univ. Ann. Chem. 20 (2), 165-179.

Barrón, D., Jiménez-Lozano, E., Cano, J., Barbosa, J., 2001. Determination of residues of enrofloxacin and its ciprofloxacin metabolite in biological materials by capillary electrophoresis. J. Chromatogr. B 759, 73-79.

BEUC, 2014. Bureau Européen des Unions de Consommateurs. European Consumer Organization. Antibiotic use in livestock: Time to act. BEUC-X-2014-043 of 11 June 2014, 01-26.

Bousova, K., Senyuva, H., Mittendorf, K., 2013. Quantitative multi-residue method for determination antibiotics in chicken meat using turbulent flow chromatography coupled to liquid chromatography-tandem mass spectrometry. J. Chromatogr. A 1274, 19-27.

Companyo, R., Granados, M., Guiteras, J., Prat, M.D., 2009. Antibiotics in food legislation and validation of analytical methodologies. Anal. Bioanal. Chem. 395, 877-891.

De Sarro, A., De Sarro, G., 2001. Adverse reactions to fluoroquinolones. An overview on mechanistic aspects. Curr. Med. Chem. 8, 371-384.

EC, 2002. Council Regulation 2002/657/EC of 12 August 2002. Implementing Council Directive 96/23/EC concerning the performance of analytical methods and the interpretation of results. Off. J. Eur. Commun. L 221/8, 17.08.2002.

EU, 2010. Council Regulation (EU) No. 37/2010 of 22 December 2009, on pharmacologically active substances and their classification regarding maximum residue limits in foodstuffs of animal origin. Off. J. Eur. Commun. L 15/1, 20.01.2010.

EMEA, 1996. European Agency for the Evaluation of Medicinal Products. Approach towards harmonization of withdrawal periods (EMEA/CVMP/036/95). Committee for Veterinary Medical Products.

Ferrari, S.P.G., Bonassa, K.P.D., Coelho, M.B., Ferreira, C.R., Costa, H.F., Jara, J.L.P. Miguel, M.C.V., Reyes, F.G.R., Eberlin, M.N., Nogueira, G.P., Simas, R.C., 2015. High precision and selectivity for quantitation of enrofloxacin and ciprofloxacin in five chicken tissues using solid phase extraction and ESI LC-MS/MS for application in monitoring residues. Anal. Methods 7, 3291-3297.

Garcia, M.A., Solans, C., Hernandez, E., Puig, M., Bregante, M.A., 2001. Simultaneous determination of enrofloxacin and its primary metabolite, ciprofloxacin, in chicken tissues. Chromatographia 54, 191-194.

Garcia-Ovando, H., Gorla, N., Weyers, A., Ugnia, L., Martinez, L., Giacomelli, N., Liboa, R., Chiostri, E., Davicino, R., 2000. Enrofloxacin liquid-liquid extraction from chicken muscle and HPLC detection. J. Liq. Chromatogr. Relat. Technol. 23, 2391-2397.

Goetting, V., Lee, K.A., Tell, L.A., 2011. Pharmacokinetics of veterinary drugs in laying hens and residues in eggs: a review of the literature. J. Veterinary Pharmacol. Ther. 34, 521-556.

Górniak, S.L., 2011. Sulfas, quinolonas e outros quimioterápicos. In: Spinosa, H.S., Górniak, S.L., Bernardi, M.M. (Eds.), Farmacologia Aplicada à Medicina Veterinária, fifth ed., pp. 436-439 Rio de Janeiro.

JPL, 2006. The Japanese Positive List System for Agricultural Chemical Residues in Foods. MRLs of agricultural chemicals, feed additives and veterinary drugs in foods. Ministry of Health Labour Welfare Japan.. http://www.ffcr.or.jp/zaidan/ ffcrhome.nsf/pages/mrls-p/ (Accessed 1 March 2016).

Kukanich, B., Gehring, R., Webb, A.I., Craigmill, A.L., Riviere, J.E., 2005. Effect of formulation and route of administration on tissue residues and withdrawal times. J. Am. Veterinary Med. Assoc. 227, 1574-1577.

Moema, D., Nindi, M.M., Dube, S., 2012. Development of a dispersive liquid-liquid microextraction method for the determination of fluoroquinolones in chicken liver by high performance liquid chromatography. Anal. Chim. Acta 730, 80-86.

Palermo Neto, J., 2004. Fatos sobre legislação e uso de antibióticos como aditivos em rações. Avic. Ind. 1124, 28-32.

Pena, A., Silva, L.J.G., Pereira, A., Meisel, L., Lino, C.M., 2010. Determination of fluoroquinolone residues in poultry muscle in Portugal. Anal. Bioanal. Chem. 397, 2615-2621.

Pereira, A.M.P.T., 2009. Determinação de resíduos de fluoroquinolonas em amostras de tecido muscular de frangos e respectivo impacto na saúde humana. Dissertação: Mestrado em Saúde Pública. Faculdade de Medicina, Universidade de Coimbra, Coimbra

Rusu, A., Tóth, G., Szõcs, L., Kökösi, J., Kraszni, M., Gyéresi, Á., Noszál, B., 2012. Triprotic site-specific acid-base equilibria and related properties of fluoroquinolone antibacterials. J. Pharm. Biomed. Anal. 66, 50-57.

San Martín, B., Cornejo, J., Iragüen, D., Hidalgo, H., Anadón, A., 2007. Depletion study of enrofloxacin and its metabolite ciprofloxacin in edible tissues and feathers of white leghorn hens by liquid chromatography coupled with tandem mass spectrometry. J. Food Prot. 70 (8), 1952-1957.

San Martín, B., Cornejo, J., Lapierre, L., Iragüen, D., Pérez, F., Hidalgo, H., Andre, F., 2009. Withdrawal time of four pharmaceutical formulations of enrofloxacin in poultry according to different maximum residues limits. J. Veterinary Pharmacol. Ther. 33, 246-251.

Severo, M.P.F., 1999. Resíduos em produtos de origem animal no Brasil: o papel do Ministério da Agricultura e Abastecimento. In: Simpósio sobre as Implicações Socioeconômicas do Uso de Aditivos na Produção Animal. Piracicaba, pp. 31-44.

$\mathrm{VICH}, 1999$. International cooperation on harmonization of technical requirements for registration of veterinary medicinal products. Validation of analytical procedures: Methodology - VICH GL2. http://www.vichsec.org/guidelines/ pharmaceuticals/pharma-quality/analytical-validation.html (Accessed 2 February 2012).

Yu, H., Tao, Y., Chen, D., Pan, Y., Liu, Z., Wang, Y., Huang, L., Dai, M., Peng, D. Wang, X., Yuan, Z., 2012. Simultaneous determination of fluoroquinolones in foods of animal origin by a high-performance liquid chromatography and a liquid chromatography tandem mass spectrometry with accelerated solvent extraction. J. Chromatogr. B 885-886, 150-159. 